\title{
The Potential of Regional Trade Agreements for Extending Social Protection in Health: Lessons Learned and Emerging Challenges
}

\author{
Jens Holst ${ }^{*}$
}

\author{
Consultant for German Technical Cooperation (GTZ), Germany
}

\begin{abstract}
Globalisation induces nation states to build marketplaces that span various countries with the objective of facilitating trade and improving economic competitiveness. International experiences gained from three common markets, the European Union (EU), North American Free Trade Agreement (NAFTA) and Common Southern Market (MERCOSUR) allow for drawing some general conclusions that might be helpful for guiding similar processes in other regions and preparing them better for the challenges of human and social rights in open economies. Analysis of existing trade agreements shows that even relevant differences in design, structure, financing, coverage and regulation of health systems in member states do not necessarily prevent them from implementing common block-wide social protection and health service arrangements. Public health activities, epidemiologic surveillance and disease prevention have the potential of being starting points for shared activities of member states in the health field. Bi- or multi-national enterprises are eligible to become focal points of cross-border arrangements and regulations, especially if they are public or publicly administered. In general, coordination and cooperation between countries can be tried out or applied first in border regions where there is a high flow of goods, services and persons.

When it comes to implementing the social dimension in the policy and priority setting of trade agreements, motivating spirit, driving forces and the concordance of value-sets in member states are crucial conditions. National governments planning to set up or join regional trade agreements have a broad decision margin regarding the extent to which they include social and human rights in regional trade arrangements. International organisations that are promoting regional economic blocks such as the World Bank, the World Trade Organisation and others should inspire political and economic decision-makers to consider health and social protection as crucial points for international trade. There is a broad array of political options between either strengthening the social dimension of common markets or dissolving the existing regional cohesion in favour of entering strictly market-driven blocks.
\end{abstract}

\section{INTRODUCTION}

In the context of globalisation, an increasing number of multinational free-trade regions have developed during the last several decades into economically integrated areas or regional common markets. The European Union (EU), which arose from the former European Economic Community (EEC), ${ }^{1}$ the North American Free Trade Agreement (NAFTA), and the Southern Common Market (MERCOSUR) ${ }^{3}$ are examples of regional trade agreements established in the second half of the twentieth century. More recent regional initiatives like the ASEAN Economic Community (AEC), ${ }^{4}$ the Central

*Address correspondence to this author at Heimstrasse 3, D-10965 Berlin, Germany; Tel: +49-(0)30-69599350; Fax: +49-(0)30-25491556;

E-mail: drjensholst@web.de

\footnotetext{
${ }^{1}$ The EEC was created by Belgium, France, Germany, Italy, Luxemburg, and the Netherlands. After several enlargement processes, the EU currently comprises 27 members countries, including the six original states plus Austria, Bulgaria, Cyprus, Czech Republic, Denmark, Estonia, Finland, Greece, Hungary, Ireland, Latvia, Lithuania, Malta, Poland, Portugal, Romania, Slovakia, Slovenia, Spain, Sweden and the United Kingdom. ${ }^{2}$ Canada, the United States of America and the United States of Mexico. ${ }^{3}$ Argentina, Brazil, Paraguay and Uruguay; with Bolivia, Chile and Peru as associated members and Venezuela as an emerging member state.

${ }^{4}$ Brunei Darussalam, Cambodia, Indonesia, Lao PDR, Malaysia, Myanmar, Philippines, Singapore, Thailand, and Vietnam.
}

American Free Trade Agreement (CAFTA) ${ }^{5}$, the Common Market for East and Southern Africa (COMESA) ${ }^{6}$ or the East African Community (EAC) ${ }^{7}$ are emerging with a view to making member countries more competitive and less dependent on world market fluctuations. Economic and trade integration advances in an unsynchronised way and varies according to the nature of goods and services. It tends to be distinctly faster for traditional goods and services as well as for innovative technological developments, and usually much slower amongst social goods and services.

For many years, the worldwide dominance of the economic over the social imperative has implied that social policy was considered secondary for the development of countries and societies. Likewise neoclassical economists believed that the pace of regional economic integration is the sole or at least the most important determinant of the growth of economies and regions, and that the social dimension can only evolve after having achieved a certain level of economic development. In other regions, however, economic globalisation has shown to be prone to adverse and

\footnotetext{
${ }^{5}$ Costa Rica, El Salvador, Guatemala, Honduras, Nicaragua, and the United States of America; since January 2004, the Dominican Republic joined the CAFTA that is now officially called DR-CAFTA.

${ }^{6}$ The following 19 countries are members of the COMESA: Burundi, Comoros, the Democratic Republic of Congo, Djibouti, Egypt, Eritrea, Ethiopia, Kenya, Libya, Madagascar, Malawi, Mauritius, Rwanda, Seychelles, Sudan, Swaziland, Uganda, Zambia and Zimbabwe [1]. ${ }^{7}$ Burundi, Kenya, Rwanda, Tanzania and Uganda.
} 
potentially harmful effects on health care and social cohesion, and trade liberalisation often has detrimental consequences on health services and social protection [2]. There is convincing evidence for assuming that growing economic interdependence and movement of capital tend to favour the wealthier citizens of all nations and worsen the income distribution among and within many countries [3, 4]. Likewise, the negative correlation between poverty and health [5] and the links between globalisation, poverty, and adverse health effects are well established [6]. Moreover, impoverishment due to ill health and a lack of social protection has a negative impact on productivity, economic growth and sustainability of trade [7].

There are thus good reasons that would justify health, education and social protection as basic conditions for integrating markets at the regional or even global level. The historical importance of public health measures for economic and commercial development has been evident during the last 150 years. And the current imbalance when it comes to accessing health services and especially social protection (in particular from high or catastrophic health expenditures) underpin the need for cross-border arrangements and international agreements that are in line with the increasing regionalisation and globalisation of trade and commerce. As transnational enterprises play a paramount role in human and economic development and migration is steadily increasing, health care and social protection have to be organised and guaranteed beyond the level of national states.

The international health community is aware of the potential effects of trade liberalisation on environmental and living conditions and on people's health. A series of recently published papers have drawn attention to the links between trade, trade agreements and health [8-13]. These papers focus especially on the challenges of the growing trade in health services [8], supplies and pharmaceuticals [9], on public health [12] and governance issues [11] and on social determinants of health [10]. These papers do not directly tackle the relevant issue of social health protection. Social security systems are, however, key determinants for adequate access to health care and play a major role in cushioning the increased vulnerability to sudden changes and increased economic insecurity. On the one hand, decision makers at national level "are in a position to ensure that domestic policies and regulations are designed to enhance social protection and to harness economic benefits of trade through redistributive policies" [10]. On the other hand, analysis of evidence and experience from existing trade agreements allows lessons to be learned and innovative strategies to be developed for achieving or safeguarding social protection in a context of open economies.

This paper focuses on the comparative presentation of health-related social policy experiences in the three regional trade agreements that have achieved a minimum level of functionality and coordination. The paper is based on the review of pertinent legal arrangements and relevant literature in view of their potential to enrich the debate on emerging common markets of developing countries and countries in transition. Following this introduction, the paper will first describe the former EEC and later EU in terms of its health and social policies, including a discussion of underlying basic principles and the stepwise achievement of the current status quo. Subsequently the paper will analyse the respective approaches of NAFTA and MERCOSUR when it comes to implementing a common health and social policy. It will also discuss the potential and constraints of both regional blocks regarding the implementation of shared social and health policy. The paper will summarise and briefly discuss the findings and will finally draw some conclusions and elaborate on lessons learned for forthcoming trade agreements.

\section{European Union}

The former European Economic Community (EEC) was the first international free-trade block, the roots of which date back to the 1950s. After several consecutive enlargement processes, the EEC has evolved into the current European Union (EU) with currently 27 member countries. The EU can look back on the longest history of coordination and shared decision-making among different nation states. The most noteworthy success is certainly the fact that what was initially the EEC and later the EU was built among countries after centuries of hostility that had even generated several wars. At the same time it has to be stressed that EU member states share a set of concepts and values based on mutual support, solidarity, and social responsibility. The European social model has developed over centuries and achieved a high level of operationalisation when the European unification process started.

The fact that health care coverage is practically universal in all EU countries has to be considered an outstanding achievement of the $\mathrm{EU}^{8}$. This is attributable to the long history of social protection in Europe, which can be traced back to professional/work-related, co-operative, guild- or craft-based local self-help charity schemes that have developed since the Middle Ages. The current health care and social protection systems are based on a set of common values and societal consensus, which are operationalised in Bismarck systems based on statutory health insurance, or in National Health Services or Beveridge systems based on taxation. Independently of the respective health care and health financing systems in place, equity, social justice and mutual support with the better-off subsidising social benefits of the poor are well-established principles all over Europe. A large majority of EU citizens support social fairness, and redistribution mechanisms institutionalised in the Bismarck and Beveridge systems. European social policies on health and social protection are structured to build successive rings of social protection, which are based either on parastatal statutory health insurance schemes, or public tax-financed health services.

European health care systems have a number of assets, which are having direct implications on social policy and social protection. Beyond universal coverage, the most

\footnotetext{
${ }^{8}$ Population coverage usually extends to all residents, but often excludes mainly unofficial migrants (sans papiers) and especially in Eastern European countries some minorities such as Roma, Sinti and others. Despite broad population coverage, both the height and depth of coverage [14] might vary from one country to the other: In some formerly socialist Eastern European countries, but also in Belgium, Sweden and Italy, patients have to pay a relatively high share of treatment costs out of their own pockets; and the benefit packages also tend to be more comprehensive in the original members states compared to those countries that joined the EU more recently.
} 
significant assets are solidarity, self-governance and subsidiarity [15]. Solidarity is operationalised by riskindependent, income-related financing and equal access to a well-defined benefit package. Subsidiarity in the European sense goes beyond providing support for the most needy; it rather refers to delegating responsibility and decisionmaking to the lowest possible level of society capable of shouldering the burden and/or solving the problem. This principle is widely applied both within the EU and within member states: Autonomous professional players within the health care system take over certain tasks and obligations which are typically defined as public, and the Government concentrates on its role of regulating and supervising the overall performance of the health system.

In this regard, the "Council Conclusions on Common Values and Principles in European Union Health Systems 2006/C 146/01" has to be considered a key document [16]. It contains the following basic definitions by the Council of the then 25 member states: "The health systems of the European Union are a central part of Europe's high levels of social protection, and contribute to social cohesion and social justice as well as to sustainable development. The overarching values of universality, access to good quality care, equity and solidarity have been widely accepted in the work of the different EU institutions. Together they constitute a set of values that are shared across Europe. Universality means that no-one is barred access to health care; solidarity is closely linked to the financial arrangement of our national health systems and the need to ensure accessibility to all; equity relates to equal access according to need, regardless of ethnicity, gender, age, social status or ability to pay. EU health systems also aim to reduce the gap in health inequalities, which is a concern of EU Member States; closely linked to this is the work in the Member States' systems on the prevention of illness and disease by inter alia promotion of healthy lifestyles" [16].

These principles are mentioned as well in the updating of the Lisbon Agenda in 2005, where universality, equality, solidarity and efficiency in national healthcare services are among the necessary conditions required for promoting economic growth. A preparatory document of 2004 makes reference to the goals of the Lisbon strategy in 2000, underlining how a universally accessible healthcare system has a crucial impact on social cohesion. In this regard, the Lisbon Agenda (that has been passed in most member countries but is still in the process of being finally approved) states the following: "The provision and funding of health and long-term care are key elements of the economic and social modernisation strategy launched in Lisbon in March 2000. The core principles and objectives of EU health and social policy are social cohesion, universal access, fair financing and solidarity.

Social cohesion is reinforced by access to quality care based on the principles of universal access, fairness and solidarity. Improving access to care is acknowledged to be a way of mobilising the potential of the EU's workforce in the context of a shrinking active population. Recent studies show that care policy should be seen as an active employment policy tool, as it increases the social and occupational integration prospects of jobseekers. However, the draft 'Joint report on social inclusion' shows that the most disadvantaged groups have more serious, health problems. They often find it more difficult to have access to care because of long waiting times, high treatment costs in relation to their income, complex administrative procedures and, more generally, insufficient prevention (screening, vaccination) $[\ldots] .$. .

One real success of European care systems has been to make high-quality care accessible to all, hence achieving universal access, fairness and solidarity in access to health care. Member states are required to provide a safety net against ill health-, accident- or old age-related poverty, for both the beneficiaries of care and their families. Universal coverage must be based on solidarity according to the structure of each system, benefiting in particular those on low incomes and those whose health status requires intensive, long or expensive care, including palliative and end-of life care. [...] Care systems must therefore develop a care package which is sufficient and well adapted to the needs of the population." [21].

According to the EU conventions, the European Commission (EC) ${ }^{9}$ guarantee of universal and fair access to healthcare services based on the principle of solidarity can be described as a basic condition for healthcare systems of EU member states. There are some constraints and difficulties, but they concern mainly the erosion of the depth and scope of public system coverage (e.g. cost-sharing arrangements and benefit packages of both tax-financed health services and public health insurance schemes) or cultural and geographical hurdles. However it has to be pointed out that the goal of universal coverage is not under discussion in the European Union and in the Member States.

The EU defines social policy, health care and other social services primarily as national affairs; and health policy and institutional reforms of health systems are primarily the responsibility of the member states. Despite the resulting heterogeneity of health care systems within the European Union, the EU Charter of Social Rights contains some aspects that build a kind of framework for national health policy. In this sense, the Treaty of the European Community (TEC) states the following: "Community action in the field of public health shall fully respect the responsibilities of the Member States for the organisation and delivery of health services and medical care. In particular, measures referred to in paragraph 4(a) shall not affect national provisions on the donation or medical use of organs and blood" [17]. However, the health policy field is undergoing a dynamic process of Europeanization. Though national policies still dominate social affairs and policy, EU laws have an increasing impact on health care provision [18]. The socalled open method of coordination within the European multi-level system is increasingly applied in the field of health policy. This method is a procedure for developing common policies beyond the traditional regulation and guidelines established in the EU Treaty on European Union. The idea is to foster political commonalities among member states rather by advancing a process of coordination and learning than by transferring resources of control which leave the formal authority of the member states intact [19].

\footnotetext{
${ }^{9}$ Supranational EU institution composed by 27 commissioners, one from each member state. The EC is an executive body and acts as a kind of EU Government.
} 
The open method of coordination was defined for the first time in the conclusions drawn by the Council of Lisbon and encompasses the following core elements:

- $\quad$ Setting guidelines for the development of individual policy areas, including a timetable for achieving short, medium, and long-term objectives.

- $\quad$ Establishing quantitative and qualitative indicators and benchmarks to facilitate comparison of national practices and identify sound processes.

- Adoption of European guidelines in the Member States' policies by developing concrete objectives and enacting appropriate measures.

- Regular supervision, evaluation, and mutual examination of measures taken and progress achieved [20].

Cross-border cooperation first started in Euro-regions where larger populations or business belonging to different EU countries are in close geographic vicinity. The need for international cooperation was highest in those regions where the nearest providers were located across the border in a neighbouring country. These regions were the first to open the respective national systems to foreign nationals by applying Forms E 106, E 111, E112 and E114. ${ }^{10}$ Health financing institutions and health care providers tested and established the first cross-border contractual relationship in these areas. Cross-border health care is certainly not a priority issue in European health systems, and its impact remains restricted. It is, however, of considerable relevance to those living on the borders of their home state [22] and for highly specialised and, thus, expensive health services that still require prior authorisation which is usually given by the proper social security institutions [23]. Meanwhile some health insurance funds have opened offices in neighbouring countries or even further away such as the German statutory sickness fund AOK on the Mediterranean island of Mallorca belonging to Spain (see [22] and [24]). Access difficulties still exist, however, for certain groups and individuals, compromising their social and occupational integration ability. Moreover, inequalities in the regional distribution of care facilities or inadequate supply compared to need can lead to long waiting lists. Staff recruitment and management difficulties can cause similar problems [15].

More than ten years ago, the European Union had already achieved major advances in the regulation of health rights reciprocity and may be considered the most developed economic block in this regard. This culminated in the implementation of reciprocity or portability of social protection entitlement within the EU. Since 2003, citizens and permanent residents are automatically protected in any EU country where they are staying, visiting or working because they are allowed to access the health system of any member state without paying for health care out of their own pocket. Any claims due are reimbursed by the financing institution in the home country, either by statutory health insurance funds or by public health systems. The European health care card has not yet been implemented in all member states, and cross-country claim processing is still developing in the field. However, the Regulations $1408 / 71$ and 574/72 (O. J. L149/2 and O. J. L74/1/72) complement the free

\footnotetext{
${ }^{10}$ For further details see [18].
}

movement of persons. Forms E111 (extended) and E112 establish portability of health coverage entitlements for EUcitizens throughout the European Community and remove obstacles to cross-border mobility of workers.

EU regulations relating to the portability of social protection entitlements are certainly the most advanced example in this field, especially with regard to the rights of European citizens. The extensive legal provision of EU Regulation 1408/71 ensures far-reaching reciprocity and portability of social security benefits within the EU, to the extent that EU citizens do not suffer any disadvantages in terms of social protection by moving from one member state to another. In 2003, the EU passed Regulation 859/2003, which extends the provisions of Regulations 1408/71 even to third-country nationals. Today migrant workers from outside the EU enjoy the same rights as EU nationals with respect to the portability of social security entitlements when moving within the EU. Directive 109/2003 gives third-country nationals (except refugees) who have resided in any EU member state for a minimum of five years the same rights and obligations as EU nationals in terms of employment, education, and social protection benefits. This includes in particular the right to reside in all other EU member states and fully benefit from all EU freedom-of-movement provisions.

The level of social protection and portability of entitlements achieved in the EU is certainly high compared to other common markets and reflects both the long-standing development of the European block and the degree of common sense regarding the social dimension of trade agreements. Social and health policies play clearly a more explicit and guaranteed role in the EU than in MERCOSUR and NAFTA, the two other economic blocks that are described below.

\section{MERCOSUR}

The following paragraphs analyse the social and health policies experiences of MERCOSUR (or MERCOSUL in Portuguese), which is a much more recent regional trade agreement in South America compared to that in the EU. MERCOSUR was created in 1991 through the Asunción Treaty signed by the governments of Argentina, Brazil, Paraguay and Uruguay. Bolivia and Chile became associated members in 1996 and 1997 respectively, followed by Peru (since 2003), Colombia and Ecuador (since 2004). In 2006, Venezuela signed the membership treaty, but formal incorporation is not yet concluded. Despite the association of potential new member states, the MERCOSUR agreement is still restricted to the four founding countries.

According to the level of integration of both population coverage and institutional functions, health care systems in Latin America can be classified into four basic models (see Fig. 1). MERCOSUR member countries belong to different models and vary considerably in terms of organisation and financing, ranging from the public contract model to atomised private systems [25]. Brazil, the largest country and economy in the region has implemented a tax-financed universal health protection system, and Argentina has a mix of co-operative, public and private and other health insurance schemes. Social health protection in Uruguay is historically based on mandatory private insurance, and is currently 


\section{Typology of health system models in Latin America}

\begin{tabular}{|l|c|c|}
\hline \multirow{2}{*}{ Population } & \multicolumn{2}{|c|}{ Institutional functions } \\
\cline { 2 - 3 } & Vertical integration & Separation \\
\hline $\begin{array}{l}\text { Horizontal } \\
\text { integration }\end{array}$ & $\begin{array}{c}\text { Unified public model } \\
\text { (e.g. Cuba, Costa Rica) }\end{array}$ & $\begin{array}{c}\text { Public contract model } \\
\text { (e.g. Brazil) }\end{array}$ \\
\hline Segregation & $\begin{array}{c}\text { Segmented model } \\
\text { (most Latin American } \\
\text { countries) }\end{array}$ & $\begin{array}{c}\text { Atomised private model } \\
\text { (e.g. Argentina, Uruguay) }\end{array}$ \\
\hline
\end{tabular}

Source: [17]

Fig. (1). Typology of health system models in Latin America.

developing into a tax-based system like in Brazil. Last but not least, Paraguay only offers a set of schemes for about $20 \%$ of the total population. The countries associated to MERCOSUR also offer a broad array of different health care and social protection systems. Venezuela has a mix of the former segregated social health insurance system with innovative publicly financed "popular" health providers. Bolivia and Peru have tax-based social health programs for the poor, social health insurance for the employed and private insurance for the better off, while Chile offers broad population coverage through a statutory health insurance fund with private insurance as an alternative for the upper socio-economic strata.

Health was not a priority in the foundation of MERCOSUR and in its early beginnings. It only started to gain in importance in 1995 through the establishment of the Health Minister Assembly (Reunión de Ministros de Salud) as the highest hierarchical political MERCOSUR institution in the field of health care. The Assembly includes the responsible ministers of the associated member states and has the role of defining health policy and health strategies for MERCOSUR. Most of the regulations deal more with issues related to public health surveillance, control and standardisation of sanitary products rather than with issues involving the production and registration of medications, integration and reciprocity of services to be mutually delivered to the member countries' citizens. In 1996, MERCOSUR approved the implementation of the technical Working Subgroup 11 (SGT 11) on Health for harmonizing legislation and coordinating member state activities relating to health care services, goods, commodities and products, epidemiologic and sanitary surveillance and controls [26].

With regard to block-wide agreements in health, MERCOSUR governments focus mainly on disease control and epidemic prevention, while cross-border accessibility of health services, portability of social protection and equal social and labour conditions have not yet become a priority. In this spirit Brazil has started to freely distribute yellowfever vaccines in Bolivia, and at the same time implemented the requirement for Bolivians to be vaccinated for yellowfever before entering Brazil. Similarly, attempts are being made to regulate medical care in the Triple Frontier Region shared between Argentina, Paraguay and Brazil that is crossed everyday by vast numbers of migrants and thousands of tourists, in order to reduce the risk of disease transmission [27]. Interesting focal points are the bi-national hydroelectric power plants run by Brazil and Paraguay and by Argentina and Paraguay, respectively, because social rights established in one country also have to be provided to the workers of the other nation involved [28]. The Declaración Socio-Laboral del Mercosur promulgated in 1998 may have fallen short of the trade unions' desire but it is nonetheless an important statement of labour rights, non-discrimination, and involvement in social dialogue. There is certainly much comparative social policy research conducted and valuable lessons are being learned from best practice in the South American region [29].

Besides some reciprocal social security entitlements, MERCOSUR has adopted a labour and social declaration, common regulations on pharmaceuticals, and joint health and safety inspections. Moreover, agreements have been reached to mutually recognise education credentials, degrees and diplomas across member countries. Technical cooperation has occurred in most social areas, with proposals for a regional social fund and a few regionally funded projects in border areas, for example. In January 2007, the MERCOSUR Council approved the establishment of a Social Institute, to be based in Asunción, Paraguay, with the mandate to elaborate regional social policies, to systematise and update regional social indicators and to promote the exchange of good practices in the social field and cooperation mechanisms [30].

The WHO Commission on Macroeconomics and Health has proposed the implementation of a Subregional Commission of Health and Development for MERCOSUR representing Argentina, Brazil, Paraguay and Uruguay. The objective of the MERCOSUR Commission of Health and Development would be to "incorporate and emphasize the social and health dimensions on the agenda of the commercial, political and economic integration of MERCOSUR countries, and as one of the determinants to address poverty reduction and sustainable development of these countries" [31]. The MERCOSUR Commission of Health and Development is promising to extend social health protection in the MERCOSUR. It will focus on the health of migrants and people living in border areas and contribute towards building an institutional network between the health, finance, and economic planning decision-makers in the 
participating countries. Moreover it will involve the civil society in promoting widespread consensus and support, and will provide technical support to MERCOSUR countries to help them develop sound investment plans and share experiences with the other members [31].

Up to now, however, there is no treaty in place, which explicitly regulates the issue of reciprocity of health protection systems and health insurance portability among Member States. In practice, however, national or local public health services provide emergency care to foreigners without any previous agreement or financial compensation mechanisms. The Argentinean government is actively attempting to broaden migrants' access to social benefits and has enacted domestic measures since 2004. Today Argentina allows citizens of other MERCOSUR countries to take advantage of public health services and education facilities, and non-Argentinean residents even have the right to vote in municipal elections if they possess a national identity card [32].

Despite the noticeable efforts to enhance the social dimensions of MERCOSUR, attempts to ensure access to health care for all member state citizens in any country of the Southern Common Market, regardless of their place of origin or residence, do not yet imply any systematic and reliable approach towards the portability of rights and entitlements. In view of the uneven financing conditions and arrangements of health protection in MERCOSUR member states, however, this may lead to adverse incentives as long as there is no common international regulation. Due to the priority focus on economic aspects and trade liberalisation, the most important progress in health are the harmonisation of sanitary control rules for the exchange of products, some regulations of epidemiologic surveillance and disease control, exchange of information related to health and some measures to react to the increasing flow of citizens between countries.

\section{NAFTA}

The following section presents the various approaches of the North American Free Trade Association (NAFTA, or TLC in Spanish) regarding social and health policies adopted in North America. NAFTA is even more recent than MERCOSUR and was created in 1994 by Canada, United States of America and Mexico. It includes three countries with huge unevenness regarding the socio-economic development and quite different concepts of society, economy, basic rights and health policies. NAFTA represents a limited approach to trade blocks because the treaty in question involves solely the movement of goods, services, and capital, but does not imply the level of integration of the EU. Additionally, the differences between the two industrialised nations (Canada and the USA) and one country in transition (Mexico) are huge compared to the differences between poorer and richer member states of the EU [25]. Moreover, NAFTA was and is a widely hegemonic block designed according to the predominant economic power of the US. In the light of this, it is not surprising that NAFTA faces many more obstacles in the implementation of joint co-operation programs, effective regulation, integration and reciprocity in health issues than the EU and even compared to MERCOSUR [33]. In view of the profound differences between the health systems in the United States of America, Canadian and Mexico in terms of financing, structure and population coverage, health integration is almost non-existent in NAFTA.

The US health system is widely known as being marketdriven with a strong emphasis on private health insurance and private providers. Meanwhile, however, about $50 \%$ of overall spending on health is financed by public resources. Canada has a Beveridge-type health financing system with a mix of public and private health care providers. And Mexico is a typical example of a segmented Latin American health system (see Fig. 1 above) with a mix of Bismarckian social health insurance for the formally employed, a private subsystem for the better-off, and tax-financed health services for the poor and for currently uncovered informal sector workers; the latter is only recently developing into a subsidised health insurance scheme.

Comparable to other economic treaties, NAFTA affects access to health care services by citizens of member states while visiting, working or residing in another, especially for vulnerable groups such as low-income and rural workers, domestic employees and others. Achieving a common understanding and agreement on citizen's freedom of movement and residence, however, is a major challenge for NAFTA. Notorious differences exist in the concepts and ideologies behind health protection and the delivery of health services in the three member countries. In Canada, non-profit public authorities safeguard universal access and the portability of entitlements from one province to another, and service provision is under public regulation. In Mexico, a national authority is likewise responsible for the provision and coordination of private and public health services, the latter being the larger proportion. The US health system is mainly private and market-driven, accomplished by an increasing public component through tax-financed social protection for the elderly and the poor [34].

Meanwhile, some initiatives have developed in the field of labour security, occupational health and work accidents among NAFTA countries, aiming at implementing common occupational and environmental health parameters that allow for complying with international provisions. At the same time, the economic partnership is expected to generate substantial investments in health and social services; NAFTA is also expanding opportunities for international consortia and joint projects in health work and training for overcoming specific constraints in either country [35]. However, after more than 15 years since the start of NAFTA, the debates on portability of entitlements, integration of health rights and other related topics are far from even starting. Among other reasons, this is certainly a consequence of the differences regarding administration and coverage of the health systems of the three countries forming NAFTA [27].

In fact, there is an obvious contradiction between the easy and continuously increasing flow of goods and services between the three member states and the restrictive US immigration policy that prevents mainly Mexicans from accessing the North American labour market. Working migration from the South to the North is mostly illegal, and the social dilemma derived from people's lack of freedom of movement is clearly visible in the extensive fences and 
sophisticated defence systems implemented on the USMexican border. Despite the strong immigration restrictions with regard to the working force and other citizens, more than 25 million people of Mexican origin are residing in the USA, and they have even less health insurance coverage than the average citizen in the USA with about one in every six persons lacking health insurance.

The first attempt to resolve this problem was to offer voluntary insurance for individuals of Mexican origin residing in the USA through the Mexican social insurance fund IMSS but this was not very successful. By the end of the 1990s, the newly established Mexico-USA Commission started to focus on the health situation at border areas that turned out to be worse in the USA than in Mexico. Some measures for improving the health status have been started through public organisations and philanthropic organisations, but there is still much room for intensifying these efforts and to include preventive and promotive activities in the program. However, the starting point and policy objectives of each country are different. While the USA places priority on the fight against AIDS, other infectious diseases and potential bio-terrorism, Mexico focuses much more on universal coverage and equal access to health care. The general assumption that the implementation of NAFTA would facilitate border binational cooperation and, by this, contribute to improve the health status of border residents turned out to be unrealistic. A complex setting of political, professional, legal, administrative, cultural and social barriers prevented joint programs from being implemented or being successful, and setting up a common market has not helped to improve health cooperation or the health status of people residing on both sides of the border [3].

Concerning the Northern border between NAFTA member states, there is some health-related movement and exchange to be observed. US-citizens, and also better-off Mexicans, travel to Canada to receive mostly elective medical services [36]. Non-Canadian NAFTA-residents benefit from health care that they cannot afford or do not wish to pay for in their country of residence because it is practically free of charge in Canada. For Canadian providers, however, the cross-border demand for health care increases the risk of being charged in the patients' home countries for malpractice [36]. At the same time, some higher-income Canadians avoid waiting periods at home and prefer to get prompt treatment for usually high out-of-pocket costs. Despite the individual movement of people seeking care on the other side of the border, no serious attempt has been made to implement joint strategies and to establish a contractual framework for assuring access to adequate health care. Among NAFTA member states, cooperation in the field of health care is limited to isolated or individual initiatives and is far from providing a pathway towards harmonisation. Thus, NAFTA shows that even when pursuing integration, participant countries prefer to maintain their national priorities, their management styles, and their own ways of financing health.

Based on the overarching goal of economic and freetrade agreements, private health care corporations are benefiting from reduced customs duties and freedom of investment like any other private companies. The exportation of managed care to Mexico appeared as a promising opportunity mainly for those US corporations that turned out to be insufficiently prepared for surviving the increasing pressure on the competitive national market $[34,37]$. For example, the enterprises International Business Machines Corp. (IBM), Johnson \& Johnson, Bristol-Myers Squibb, and Hewlett-Packard which are running operations in Mexico City have formed a consortium to develop and promote managed-care programs [38]. Investors consider managed-care organisations in Latin America as a potentially lucrative business [39]. The pressure on Mexico to allow privatised health care in place of mandatory social protection was mostly felt in the border region where assembly plants have boomed as a consequence of Mexico's cheap labour force in combination with a NAFTA provision allowing companies to send products duty-free into the United States, Mexico or Canada if the products are made in any of those countries. The fact that workers in the assembly plants were exposed to waiting lists and the temporary unavailability of special services turned out to be incompatible with a forprofit free-trade priority setting. Lobby groups tend to use constraints in health service delivery for promoting private health care and private health financing. North US corporations have long discovered Latin American social security funds as a highly lucrative market; and HMO corporations expect especially big opportunities in Mexico because of the considerable resources administered by the public Social Security Institute IMSS [39]. Public health experts criticise executives responsible for the exportation of managed care for focussing mainly on financial rewards and for neglecting other objectives such as preventive care, education, research and quality control that have been valued historically, at least by some HMOs in the United States of America.

\section{SUMMARY}

For many years, the dominance of the economic over both the health and social imperatives has implied that the political framework has seen healthcare and social protection just as a component for trade [13]. Experiences of the three regional trade agreements described above differ remarkably in many aspects and especially in the level of social cohesion achieved. Nonetheless, the differences are meaningful with regard to the policy options and the potential of common markets. Globalisation of international relationships, economic and commercial activities, and human migration is increasingly requiring national states to look for allies and to organise themselves in international alliances. Since the creation of the European Union (EU) as the first modern economic block ever, a series of other common-market initiatives have emerged during the last 25 years. Mainly the South American MERCOSUR and the North American NAFTA have achieved a relevant degree of organisation and implemented a series of arrangements in the field of economic and commercial activities.

As a matter of course, all common markets and economic unions put priority on trade liberalisation, economic exchange and financial stability. In all likelihood, common markets tend to perceive the citizens residing in member states mainly as human resources who are playing a certain function in the economic process, but are not immediately considered as citizens with civil rights beyond their work force and consumer role. This is the reason why social policy 
and the freedom of movement usually play a secondary role in regional free-trade initiatives. Meanwhile, action informed by theory and praxis has focused on the adverse effects of economy-driven integration and globalisation on people's health. Opposition to policies that generate detrimental effects on health services and social health protection has increased worldwide. This is more evident and drastic in settings where for-profit corporations are strong and powerful, and where lucrative business markets attract transnational companies.

The pursuit of free trade is a social process. Integration might be a vision, but perhaps also a starting point. How policy-makers and stakeholders mobilise to create common markets varies from one region of the world to the other. Certainly the given institutional realities in the member countries used to account for such variation [33]. However, regional economic agreements offer promising options for combining free trade with the liberalisation of people's movement and extended access to social protection and health care. Synergies between regionally orientated bottomup social movements with socially mandated international top-down organisations should be promoted for accelerating the inclusion of a social dimension into regionalism and globalisation [29]. Until now, experiences showing this potential asset of regional trade agreements are still rare and mainly visible in the EU. In fact, the freedom of movement has developed stepwise during the last five decades to the extent that all EU residents have not only the right to live in any member state, but are also entitled to all social protection benefits they have acquired in any member country. EU-wide access to health care started in border regions and some preferred domiciles of citizens. Today portability of social security entitlements guarantees all EU residents prepaid access to health care in any member state.

A complex set of arrangements and regulations is therefore required, but also the political will of decisionmakers and a certain level of consensus regarding human and social values. The close relationship between economics and health is widely proven and delivers strong arguments for assuring access to social protection and health care in a globalised world, but international experience shows that this is often not enough for implementing effective social policies. A clear vision and priority setting on social and human conditions are also indispensable; and democratic societies with high levels of participation are certainly an asset. This becomes quite evident when the experiences of other regional trade agreements are compared to the certainly longer European integration. It is important to mention the recently implemented method of open coordination as an attempt of further promoting and enhancing EU integration and social cohesion. The capacity of this instrument is continuously tested when the EU expands eastwards, and further EU-level discussion on healthcare issues seem inevitable in view of the heterogeneity of social systems, health indicators and health system outcomes [40].

MERCOSUR has made some progress in the coordination and intensification of public health activities and surveillance. Moreover, access to health care for MERCOSUR citizens has been organised in border areas with a high flow of temporary or longer-term migrants and tourists. In some ways it emulates and is influenced by the
EU model but falls short compared to the achievements of the EU in the social sector [41]. The existence of the SocioEconomic Consultative Forum with representatives of employers and trade unions is a testimony to political tradition and to EU influence [29]. In terms of regional labour and social regulations, the MERCOSUR region is certainly more advanced than other regional trade agreements in terms of codifying a common policy on labour rights. Recently, MERCOSUR member states are focussing more on the relationship between health and development and are working on the set-up of risk management and risk reduction strategies. The debate on the social dimension and social policy of MERCOSUR is mainly directed at basic issues like democratisation and democratic reforms and the implementation of mechanisms of participation, representation and regional development. The South American block is still far away from assuring freedom of movement with social protection entitlements, but some national reform processes and the promising research and work on social protection and health care show that MERCOSUR is on the right track.

Although NAFTA is almost as old as MERCOSUR, protectionism and the practically exclusive focus on trade liberalisation have prevented the North American common market from even initiating a comparable process. Issues of public health and social security services were not included in the treaty negotiations. Consumers' cross-border movement and their freedom to use health services in any part of North America are constrained because public and private health insurance plans generally lack portability. Canadian insurance polices only reimburse payments made for emergency health services utilised outside the country; and access of Mexican citizens to health services available in North America is obviously limited by the considerable restrictions of migration between the United States of America and Mexico [42]. Health activities are confined to some public health measures in border areas and a rather unsuccessful attempt to cover immigrants to the USA of Mexican origin by the social health insurance scheme of their home country. Cooperation between NAFTA member states in the field of health care is restricted to isolated or individual initiatives and far from providing a pathway towards harmonisation.

\section{CONCLUSIONS}

The former European Economic Community was a pioneer on the pathway towards economic unification. Meanwhile other regional free-trade arrangements such as the North American Free Trade Agreement and the Southern Common Market have been implemented in the Americas, and others are emerging like the ASEAN Economic Community (AEC), the Central American Free Treaty Agreement, the Common Market for East and Southern Africa or the East African Community. While the European Union that has arisen from the former European Economic Community developed a broad array of arrangements providing all citizens with comprehensive social protection in any member state, including portability of pension, health coverage and unemployment benefits, social protection has not been systematically universalised in MERCOSUR and remains to be seen in NAFTA. 
In view of the potentially detrimental effects of economic globalisation on health and health care, emerging common markets in Asia and Africa offer interesting opportunities for implementing social protection and access to health care already in the founding treaties. Both the regional trade agreements and their member states could benefit substantially from some lessons learned in other parts of the world, especially from the European Union. Emerging common markets have the potential to become promotional agencies for improving access to adequate health care and to extend social protection to unprotected society groups. At the same time, they can be important tools for enforcing the effects of international health programs. Decision-makers should acknowledge that the capacity of economic blocks goes beyond the possibilities of enhancing international exchange of goods and services. Regional trade arrangements have a large potential for expanding and improving social health protection in order to assure sustainable productivity and economic growth. The trade sector has to become far more aware of the direct and indirect effects of globalisation and international trade on people's living conditions.

\section{ACKNOWLEDGEMENTS}

This paper is based on a report prepared for the German Technical Cooperation (GTZ) as background information for a meeting on future challenges for international cooperation in health and social protection with Eastern African countries held in Arusha/Tanzania in February 2009. The author is grateful to GTZ for having commissioned the underlying research that has been extended after the submission of the report.

The author also gratefully acknowledges the very useful comments and suggestions given by Luisa Guimarães Queiroz from the Policy Department of the Brazilian Ministry of Health.

\section{REFERENCES}

[1] Mfunwa M. Achieving Free Trade Area and Customs Union: Emerging Challenges and Opportunities for Southern Africa. Presentation held on the Fourteenth Meeting of the Intergovernmental Committee of Experts for Southern Africa (ICE), 2-4 June 2008, Lusaka, Zambia.

[2] Jasso-Aguilar R, Waitzkin H, Landwehr A. Multinational corporations and health care in the United States and Latin America: strategies, action and effects. J Health Soc Behav 2004; 45: 136-57.

[3] Homedes N, Ugalde A. Globalization and health at the United States-Mexico border. Am J Public Health 2003; 93(12): 2016-22.

[4] Waitzkin H, Iriart C. How the United States export managed care to third world countries? Mon Rev 2001; 52(1): 21-35.

[5] Marmot M, Friel S, Bell R, Houweling T, Taylor S. On behalf of the Commission on Social Determinants of Health. Closing the gap in a generation: health equity through action on the social determinants of health. Lancet 2008; 372(9650): 1661-9.

[6] Wade RH. Global inequality: winners and losers. The Economist 2001; 26: 8219: 7

[7] Sachs JD, Ed. Macroeconomics and health: investing in health for economic developing. Geneva: WHO 2001.

[8] Smith RD, Chanda R, Tangcharoensathien V. Trade in healthrelated services. Lancet 2009; 373(9663): 593-601.

[9] Smith RD, Correa C, Oh C. Trade, TRIPS, and pharmaceuticals. Lancet 2009; 373(9664): 684-91.

[10] Blouin C, Chopra M, van der Hoeven R. Trade and social determinants of health. Lancet 2009; 373(9662): 502-7.

[11] Lee K, Sridhar D, Patel M. Bridging the divide: the global governance of trade and health. Lancet 2009; 373(9644): 416-22.
[12] Fidler DP, Drager N, Lee K. Managing the pursuit of health and wealth: the key challenges. Lancet 2009; 373(9660): 325-31.

[13] Smith R, Lee K, Drager N. Trade and health: an agenda for action. Lancet 2009; 373(9665): 768-73.

[14] World Health Organization (WHO) (2008). World Health Report 2008. WHO, Geneva. Available from: http://www.who.int/whr/ 2008/whr08 en.pdf

[15] Weber A, Stierle F, Hohmann J, Schramm B, Schmidt-Ehry E, Holst J. Social Protection in Health Care - European Assets and Contributions. GTZ, Eschborn 2005; Available from: http://www. gtz.de/de/dokume nte/en-social-protection-health-care-eu.pdf

[16] European Union. Council Conclusions on Common values and principles in European Union Health Systems. Official Journal of the European Union, C 146/01. Brussels: European Commission 2006.

[17] European Union. Consolidated Versions of the Treaty on European Community Union and of the Treaty Establishing the European Community. Official Journal of the European Union, C $321 \mathrm{E} / 1$, 29.12.2006. Brussels: European Commission 2006.

[18] Busse R, Drews M, Wissmann M. Consumer choice of health care services across borders. In: Busse R, Wismann M, Berman J, Eds. The European Union and Health Services - the impact of the single European market on member states, Amsterdam: IOS Press 2002.

[19] Szyszczak E. Experimental governance: the open method of coordination. Eur Law J 2006; 12(4): 486-502.

[20] Gerlinger T, Urban HJ. From heterogeneity to harmonization? Recent trends in European health policy. Cad Saúde Pública 2007; 23 (Suppl 2): S133-42.

[21] Commission of the European Community. Communication from the Commission to the Council, the European Parliament, the European Economic and Social Committee and the Committee of the Regions. $\operatorname{COM}(2004) 304$ final. Brussels: European Commission 2004.

[22] Leidl R, Rhodes G. Cross-border health care in the European Union: an introduction. Eur J Public Health 1997; 7(Suppl 3): 1-3.

[23] Hermesse J, Lewalle H, Palm W. Patient mobility within the European Union: an introduction. Eur J Public Health 1997; 7(Suppl 3): 4-10.

[24] Wismar M, Gobrecht J, Busse R. The SEM and the public procurement of Consumer Choice of medical goods across borders. In: Busse R, Wismann M, Berman P, Eds. The European Union and Health Services - The impact of the Single European Market on Member States. Amsterdam: IOS Press 2002.

[25] Frenk J, Gómez-Dantes O, Cruz C, Chacon F, Hernandez P, Freeman P. Consequences of the North Atlantic free trade agreement for health services: a perspective from Mexico. Am J Public Health 1994; 84(10): 1591-7.

[26] Acosta C, Giovanella L, Heimann L, Sánchez D, El-Khoury de Paula A, de Vasconcelos Costa Lobato L. Una agenda de investigaciones en sistemas y servicios de salud en el contexto de la integración regional: informe del Foro MERCOSUR sobre Integración Regional y Sistemas de Salud. Cad Saúde Públ 2007; 23(suppl 2): S315-S321.

[27] Medici A, Weaver-Barros B. Health policies and economic blocks. Health Technical Note, 001/2006. Washington DC: Inter-American Development Bank 2006.

[28] Holst J. Esquemas de financiamiento de salud en el Paraguay. Eschborn: GTZ 2002 Available from: http://www.gtz.de/de/dokum ente/es-esquemas-salud-py.pdf [Cited: 15 June 2009].

[29] Deacon B. The social dimension of regionalism: a constructive alternative to neoliberal globalisation? GASPP Occasional Paper No 8/2001, Helsinki: Globalism and Social Policy Programme 2001.

[30] Deacon B, Ortiz I, Zelenev S. Regional social policy. DESA Working Paper No. 37, ST/ESA/2007/DWP/37. New York: United Nations Department of Economic and Social Affairs 2007.

[31] World Health Organization. Macroeconomics and Health. Achievements through September 2004. The Americas Region. [homepage in the Internet] Geneva: WHO Available from: http://www.who.int/macrohealth/action/update/ achievements_paho/en/index.html [Cited: 26 June 2009].

[32] Sohnen E. Scratching the surface of social protection for migrants. Canadian Foundation for the Americas, Focal Point 2008; 7(5): 1213.

[33] Duina F. Varieties of regional integration: the EU, NAFTA and mercosur. J Eur Integr 2006; 28(3): 247-75. 
[34] González-Block M. Acceso a los servicios de salud en México en el contexto del tratado de libre comercio de América del Norte. In: Bolis M, Arboleda-Flórez J, Stuart H, Freeman P, González-Block M, Eds. Access to Health Services under NAFTA. Washington DC: Pan American Health Organization 1999; pp. 159-63.

[35] Poole D. NAFTA, American health, and Mexican health: they tie together. Health Soc Work 1996; 21(1): 3-10.

[36] Bolis M, Arboleda-Flórez J, Stuart H, Freeman P, González-Block M. Access to Health Services under NAFTA. Washington DC: Pan American Health Organization 1999.

[37] Franco A. La globalización de la salud entre el reduccionismo económico y la solidaridad ciudadana (I parte). Rev Fac Nac Salud Pública 2001; 19(2): 46-55.
[38] Cisneros R. Managed care makes inroads in Latin America. Bus Insur 1997; 3-4: 6 .

[39] Stocker K, Waitzkin H, Iriart C. The exportation of managed care to Latin America. N Engl J Méd 1999; 340(14): 1131-6.

[40] Duncan B. Health policy in the European Union: how it's made and how to influence it? BMJ 2002; 324(7344): 1027-30.

[41] Sánchez-Bajo C. The European Union and Mercosur: a case of inter-regionalism. Third World Q 1999; 20(5): 927-41.

[42] Gómez-Dantés O, Frenk J, Cruz C. Commerce in health services in North America within the context of the North American Free Trade Agreement. Rev Panam Salud Public 1997; 1(6): 460-5.

(C) Jens Holst; Licensee Bentham Open.

This is an open access article licensed under the terms of the Creative Commons Attribution Non-Commercial License (http://creativecommons.org/licenses/bync/3.0// which permits unrestricted, non-commercial use, distribution and reproduction in any medium, provided the work is properly cited. 